\title{
PENGARUH LATIHAN SENAM AEROBIK MIX IMPACT TERHADAP PENURUNAN PROSENTASE LEMAK TUBUH PADA WANITA PENGHUNI PANTI SOSIAL KARYA WANITA MULYA JAYA PASAR REBO JAKARTA TIMUR
}

\author{
Yuliasih $^{1}$ \\ Junaidi $^{2}$, Yasep Setiakarnawijaya ${ }^{2}$ \\ ${ }^{1}$ Program Studi Ilmu Keolahragaan \\ ${ }^{2}$ Fakultas Ilmu Keolahragaan Universitas Negeri Jakarta, Kampus B, Jakarta
}

\begin{abstract}
Abstrak. Skripsi ini bertujuan untuk mengetahui pengaruh latihan senam aerobik mix mpact terhadap penurunan prosentase lemak tubuh pada wanita penghuni panti sosial karya wanita Mulya Jaya Pasar Rebo Jakarta Timur. Penelitian ini dilakukan di Panti Sosial Karya Wanita Mulya Jaya Jalan Tat Twam Asi No. 47 Komplek Depsos Pasar Rebo,Jakarta Timur 13760 Telp. (021) 4800631. Pada tanggal 1 April - 15 Mei 2010. Metode yang digunakan adalah eksperimen dengan "One Group Pretest - Posttest Design". Sampel berjumlah 20 orang dari jumlah keseluruhan populasi wanita penghuni panti sosial karya wanita Mulya Jaya Pasar Rebo Jakarta Timur. Instrumen penelitian yang digunakan adalah Fat Calliper. Teknik Analisis Data yang digunakan adalah uji-t dengan menghitung nilai t-hitung dibanding dengan t-tabel pada derajat kebebasan n-1 dan pada taraf signifikansi 0,05. Hasil perhitungan prosentase lemak tubuh awal dan akhir setelah latihan senam aerobik mix impact diperoleh selisih rata-rata $\left(M_{D}\right)$ 2,96 dengan standar deviasi perbedaan $\left(S D_{D}\right)$ 0,94. Standar error perbedaan rata-rata $\left(S E_{M_{D}}\right) 0,22$, dalam perhitungan selanjutnya diperoleh nilai t-hitung 13,45 dan nilai t-tabel 2,09 pada taraf signifikan 0,05, dengan demikian nilai t-hitung > t-tabel yang menunjukkan bahwa hipotesa nihil $\left(\mathrm{H}_{0}\right)$ ditolak dan hipotesa alternatif $\left(\mathrm{H}_{1}\right)$ diterima. Maka dapat disimpulkan bahwa program latihan senam aerobik mix impact dapat menurunkan prosentase lemak tubuh pada wanita penghuni panti sosial karya wanita Mulya Jaya Pasar Rebo Jakarta Timur.
\end{abstract}

Kata kunci : Latihan, Senam Aerobik Mix Impact, Lemak Tubuh.

\section{PENDAHULUAN}

Pola dan gaya hidup seseorang seperti sekarang ini sangat dipengaruhi oleh perkembangan zaman. Mereka sangat dimanjakan dengan hasil penemuan alat-alat yang mudah dan praktis, sehingga mereka malas untuk bergerak diluar kegiatan rutin seharihari. Kebanyakan dari mereka lebih suka dengan segala sesuatu yang praktis dan mereka lebih mementingkan kecantikan diri daripada harus bergerak (berolahraga) demi mendapatkan kesehatan.

Masalah yang timbul pada masa kini adalah banyak orang yang tidak sehat dan tidak sedikit dari mereka yang menderita berbagai penyakit seperti obesitas, diabetes mellitus, jantung koronerdan lain-lain. Obesitas merupakan peningkatan prosentase lemak tubuh (body fat). Obesitas biasanya timbul karena pola hidup yang tidak sehat. Bisa terlihat dari gaya hidup 
yang cepat (instan) dan pola makan yang berlebihan yang tidak diimbangi dengan aktivitas yang berarti.

Lemak merupakan sumber energy bagi tubuh, keberadaannya sangat diperlukan dalam tubuh sebagai cadangan energi. Lemak dapat diperoleh dari asupan makanan yang kita konsumsi sehari-hari baik makanan yang bersumber dari hewan maupun tumbuhtumbuhan. Prosentase lemak dalam tubuh harus tetap berada dalam batasan normal. Dimana kandungan lemak yang dibutuhkan untuk pria $\pm 17 \%$, sedangkan bagi wanita $\pm 24 \%$. Seseorang yang memiliki lemak tubuh dapat dilihat dari penampilan fisiknya. Sedangkan orang yang memiliki badan atletis, sudah tentu memiliki prosentase lemak yang baik.

Salah satu penyebab kelebihan lemak dalam tubuh diakibatkan oleh makanan yang dikonsumsi. Seperti sekarang ini banyak sekali restoran atau tempat makanan yang menyediakan makanan cepat saji yang pada umumnya makanan tersebut disajikan dengan cara digoreng, yang sudah tentu kandungan lemaknya sangat tinggi.

Kelebihan prosentase lemak dalam tubuh dapat mempengaruhi penampilan seseorang. Untuk mengurangi prosentase lemak tersebut perlu adanya upaya, salah satunya yaitu dengan berolahraga seperti senam aerobic mix impact. Berolahraga saja tidaklah cukup, mengurangi konsumsi makanan yang berlemak juga perlu dilakukan.

Adalah Panti Sosial Karya Wanita Mulya Jaya yang diresmikan oleh Drs. Ali Bustan pada tanggal 9 Agustus 1977 di Jalan Sat Twan Asi RT. 008 / RW. 02 Pasar Rebo, JakartaTimur13760 Telp. (021) 4800631 dan keberadaannya diperuntukkan bagi wanita mantan PSK (Pekerja Seks Komersial) untuk dapat mengembangkan diri dengan lebih baik karena mereka melakukan senam untuk meningkatkan kebugaran jasmani dan agar dapat melakukan kegiatan seharihari dengan baik tanpa mengalami kelelahan yang berarti. Mereka dibina dan diajarkan tentang berbagai macam hal, dan salah satunya adalah olahraga senam aerobik mix impact. Selain untuk meningkatkan kebugaran jasmani, senam juga membuat mereka merasa senang bahkan juga dapat menurunkan prosentase lemak tubuh sehingga tubuh bisa menjadilebih ideal.

Panti sosial sebagai unit pelaksana teknis di lingkungan departemen sosial yang berada di bawah dan bertanggung jawab langsung kepada Direktur Jenderal Pelayanan dan Rehabilitasi Sosial sehari-hari secara fungsional divina oleh para Direktur terkait sesuai dengan bidang tugasnya.

Oleh karena itu, dalam penelitian ini peneliti memilih latihan senam aerobik mix impact atau senam aerobik dengan intensitas menengah dalam penurunan prosentase lemak tubuh. Dan penelitian ini dilakukan untuk memberikan informasi kepada masyarakat luas tentang pentingnya olahraga senam mix impact untuk menurunkan prosentase lemak tubuh.

\section{TINJAUAN PUSTAKA}

Latihan. Latihan diatas segalagalanya, adalah merupakan aktifitas olahraga yang sistematik dalam waktu yang lama, ditingkatkan secara progresif dan individual yang mengarah kepada ciri-ciri fisiologis dan psikologis manusia untuk mencapai sasaran yang telah ditentukan.

Latihan yang dilakukan secara teratur, sistematis dan berulang-ulang dengan makin hari makin menambah jumlah beban latihan akanbermanfaat terhadap peningkatan kondisi tubuh seperti yang selanjutnya dikatakan oleh Harsono, dengan berlatih secara sistematis dan melalui pengulanganpengulangan yang konstan, maka 
organisasai neurophisiologis kita akan bertambah baik, gerakan-gerakan yang semula sulit dilakukan lama kelamaan akan menjadi gerakan yang otomatis dan reflektif yang semakin kurang membutuhkan konsentrasi pusat-pusat syaraf daripada sebelum melakukan latihan-latihan tersebut.

Latihan yang baik adalah latihan yang mentaati prinsip-prinsip yang berlaku serta memperhatikan beberapa faktor yang menjadi pegangan sehingga tidak menyimpang dari tujuan yang ingin dicapai dan terhindar dari usaha yang sia-sia. Adapun prinsip-prinsip latihan yang perlu diperhatikan tersebut antara lain :

a. Frekuensi

Frekuensi merupakan suatu kepadatan kegiatan yang dilakukan, dengan demikian frekuensi latihan adalah kepadatan latihan yang terjadi atau dilakukan. Menurut Sadoso dikatakan bahwa :

Latihan paling sedikit tiga kali perminggu, baik untuk olahraga kesehatan maupun olahraga prestasi. Hal ini disebabkan ketahanan seseorang akan menurun setelah 48 jam tidak melakukan latihan, jadi kita usahakan sebelum ketahanan menurun harus sudah berlatih lagi.

Menurut Dede Kusmana dalam buku Olahraga bagi Kesehatan Jantung mengatakan bahwa sebaiknya olahraga dilakukan 3 kali seminggu pada hari yang bergantian artinya selang hari dan paling banyak 5 kali seminggu.

b. Intensitas

Intensitas adalah pembebanan yang harus diberikan dalam latihan, dimana hal tersebut tergantung pada kemampuan masing-masing orang.

Seperti yang telah kita ketahui bahwa pada saat kita melakukan aktivitas olahraga maka sedikit demi sedikit denyut nadi akan naik. Denyut nadi inilah yang dijadikan ukuran apakah latihan kita cukup atau belum. Denyut nadi yang diperbolehkan selama melakukan latihan dapat dirumuskan : Denyut Nadi Maksimal $=220-$ Umur. Denyut nadi maksimal (DNM) adalah denyut nadi yang boleh dicapai waktu kita melakukan olahraga. Takaran intensitas latihan untuk olahraga prestasi adalah 80-90\% DNM, sedangkan untuk olahraga kesehatan 72-87\% DNM. Angka-angka tersebut menunjukkan Training Zone.

c. Tempo

Tempo latihan adalah beberapa waktu yang dibutuhkan dalam suatu proses latihan atau dapat dkatakan sebagai lamanya latihan yang dilakukan.

Berdasarkan uraian diatas jelas bahwa latihan lebih efektif bila dilakukan lebih dari 30 menit dan tidak melebihi 60 menit, mengingat latihan yang dilakukan untuk mendapatkan kesehatan dan menjaga kondisi tubuh bukan untuk mengejar prestasi.

Senam Aerobik Mix Impact. Senam pertama kali diperkenalkan pada zaman Yunani kuno. Senam berasal dari kata Gymnastics, Gymnas berarti telanjang, sebab pada waktu itu orang-orang berlatih tanpa memakai pakaian. Sedangkan Gymnasium adalah suatu tempat yang dipergunakan untuk mengadakan latihan senam.

Senam di Negara Indonesia sudah dikenal sejak zaman penjajahan Belanda. Pada waktu itu namanya "Gymnastiek", zaman Jepang dinamakan "Taiso". Pemakaian istilah "senam" sendiri kemungkinkan bersamaan dengan pemakaian kata olahraga sebagai pengganti kata sport.

Senam aerobik memiliki banyak variasi dan gerakannya beranekaragam sehingga tidak membosankan dan juga diiringi bermacam-macam musik mulai dari disko, dangdut sampai house music dan jenis musik lainnya sehingga 
membuat kita bertambah semangat untuk melakukannya. Selain itu, senam aerobik biasanya dilakukan secara bersama-sama dalam satu waktu.

Manfaat yang dapat diperoleh dari melakukan senam aerobik, Lynne Brick mengatakan bahwa melakukan senam aerobik adalah cara yang baik untuk membakar kalori dan lemak, sebab group otot-otot besar bergerak secara dinamis dari bagian atas dan bagian bawah tubuh. Semakin banyak anda mengerahkan otot selama melakukan senam aerobik semakin berkilo-kilo kalori yang terbakar.

Selain membakar kalori dan lemak tubuh, olahraga ini bisa membuat kita menjadi sehat dan bugar. Dengan demikian daya tahan tubuh kita pun semakin meningkat dan kita bisa melakukan aktivitas sehari-hari tanpa mengalami kelelahan yang berarti sehingga pekerjaan bisa diselesaikan tepat pada waktunya.

Seperti halnya dengan senam aerobikmix impact, dikatakan mix impactkarena gerakan yang dilakukan adalah penggabungan dari low impact dan high impact yaitu pada gerakangerakan dimana tumit mengangkat tetapi jari-jari kaki tetap berada dilantai.Anda merasa bahwa anda seolah-olah melompat tetapi sebenarnya tidak. Senam ini lebih bervariasi sehingga setiap orang senang melakukan latihan ini. Latihan ini menggunakan musik beat per menit (BPM) antara 140-160. Dengan batasan waktu maksimal 60 menit. Beberapa contoh gerakannya : melompat terus menerus, twist, menekan dan lain-lain.

Latihan senam aerobik terdiri dari berbagai tahapan, yaitu tahap pemanasan, ini dan pendinginan. Adapun sistematika dalam penyajian latihan senam aerobik mix impact adalah sebagai berikut :

a. Pemanasan
Pemanasan adalah bagian dari satu sistem olahraga. Sebagaimana diketahui dalam keadaan istirahat denyut jantung/denyut nadi akan berada dalam keadaan normal demikian juga dengan isi/volume jantung. Sedangkan otot-otot rangka dalam keadaan kaku. Pemanasan ditujukan agar otot-otot yang akan kita gerakan mulai beradaptasi sehingga akan mencegah terjadinya cedera otot. Oleh karena itu dengan menegangkan otot maka tubuh siap untuk menerima pembebanan. Disamping itu dengan meregangkan otot tubuh maka jantung pun akan beraksi. Pemanasan dilakukan antara 5 - 10 menit.

b. Gerakan Inti

Fase latihan adalah fase utama dari sistematika latihan senam aerobik. Dalam fase ini target latihan haruslah tercapai. Salah satu indikator latihan telah memenuhi target adalah dengan memprediksi bahwa latihan tersebut telah mencapai training zone. Training zone adalah daerah ideal denyut nadi dalam fase latihan. Rentang training zone adalah 60-90\% dari denyut nadi maksimal seseorang (DNM). Denyut nadi yang dimiliki oleh setiap orang berbeda, tergantung dari tingkat usia seseorang. Berikut ini adalah rumus untuk mencari denyut nadi maksimal seseorang $(\mathrm{DNM}): \quad \mathrm{DNM}=220-$ Usia (Tahun).Dalam senam aerobik, fase inti dapat dilakukan dengan aktivitas senam aerobik mix impact selama 25 -60 menit.

c. Latihan Pendinginan

Pada periode latihan pendinginan, tekanan darah harus diusahakan berangsur-angsur turun kembali. Tidak menurun drastisapalagi melampaui tekanan darah/denyut jantung sebelum latihan. 
Metabolisme Lemak. Kata lemak berasal dari bahasa Yunani (Greece) yaitu lipos. Sedangkan dalam bahasa inggris berarti lipid. Lemak merupakan sekelompok ikatan organik yang terdiri atas unsur-unsur Carbon (C), Hidrogen $(H)$, dan Oksigen $(O)$ yang mempunyai sifat larut dalam zat-zat pelarut tertentu (zat

pelarut lemak) seperti petroleum benzene dan ether. Lemak yang mempunyai titik lebur tinggi bersifat padat pada suhu kamar yang disebut lemak atau gaji, sedangkan yang mempunyai titik lebur rendah bersifat cair disebut minyak.

Hal ini secara tegas dikatakan oleh Sunita Almatsier bahwa, Lemak merupakan sumber energi paling padat, menghasilkan 9 kalori untuk tiap gram, yaitu 2,5 $\mathrm{x}$ sumber energi yang dihasilkan oleh karbohidrat dalam jumlah yang sama sebagai simpanan lemak, lemak merupakan cadangan energi paling besar.

Jaringan lemak didalam tubuh dianggap tidak aktif, jadi tidak ikut dalam proses-proses metabolisme sehari-hari (rutin), tetapi merupakan simpanan atau cadangan energi yang kelebihan dan tidak terpakai. Pada seseorang yang berat badannya berlebih atau obesitas, dimana sejumlah lemak ini merupakan beban yang harus dibawabawa tanpa memberi manfaat yang langsung.

Jadi energi yang dibutuhkan pada waktu melakukan kegiatan jasmani terutama berasal dari glukosa dan asam lemak bebas. Pada awal kegiatan jasmani kedua bahan tersebut merupakan sumber yang utama, namun pemakaian glukosa pada tingkat ini lebih cepat. Energi pada awal kegiatan jasmani berasal dari cadangan ATP-PC otot, setelah itu didapat dari cadangan glikogen otot, selanjutnya barulah digunakan glukosa. Bila kegiatan jasmani berlangsung terus maka energi diperoleh dari glukosa yang didapat dari pemecahan simpanan glikogen hepar (glikogenolisis). Bila kegiatan jasmani berlangsung lebih dari 30 menit maka sumber energi utama adalah asam lemak bebas, yang berasal dari liposis jaringan adipose.

Oleh sebab itu, tentunya pola makan harus benar-benar kita jaga sehingga dapat mengontrol atau membatasi jumlah kalori serta lemak yang masuk dalam tubuh agar latihan yang dijalankan untuk menurunkan prosentase lemak tubuh dapat lebih efektif dibanding dengan melakukan olahraga saja, dimana dalam melakukan latihan olahraga dengan intensitas atau lamanya waktu harus sesuai dengan apa yang dikatakan diatas tadi, agar tubuh menjadi efektif dalam pembakaran lemak yang ada dalam tubuh. Manfaat simpanan lemak dalam tubuh adalah sebagai berikut:

1. Sebagai cadangan energi

2. Sebagai bantalan bagi alat-alat tubuh seperti ginjal, biji mata

3. Sebagai isolasi sehingga panas tubuh tidak banyak yang keluar karena inilah orang yang gemuk selalu merasa panas

4. Mempertahankan tubuh dari gangguan-gangguan luar seperti pukulan, bahan-bahan kimia yang berbahaya yang dapat merusak jaringan otot

5. Memberikan garis-garis bentuk tubuh yang baik dalam batas normal.

Untuk mengetahui prosentase lemak tubuh seseorang dilakukan pengukuran dibeberapa bagian tubuh dengan menggunakan alat yang bernama Skinfold Caliper pada bagian-bagian sebagai berikut :

\begin{tabular}{|l|l|l|l|l|}
\hline No & Tempat & $\begin{array}{c}\text { Arah } \\
\text { lipatan }\end{array}$ & $\begin{array}{c}\text { Patokan } \\
\text { anatomi }\end{array}$ & $\begin{array}{c}\text { Cara } \\
\text { penguku- } \\
\text { ran }\end{array}$ \\
\hline 1. & Triceps & Vertikal & $\begin{array}{l}\text { Prosesus } \\
\text { akrominal }\end{array}$ & $\begin{array}{l}\text { Pertengahan } \\
\text { jarak }\end{array}$ \\
\hline
\end{tabular}




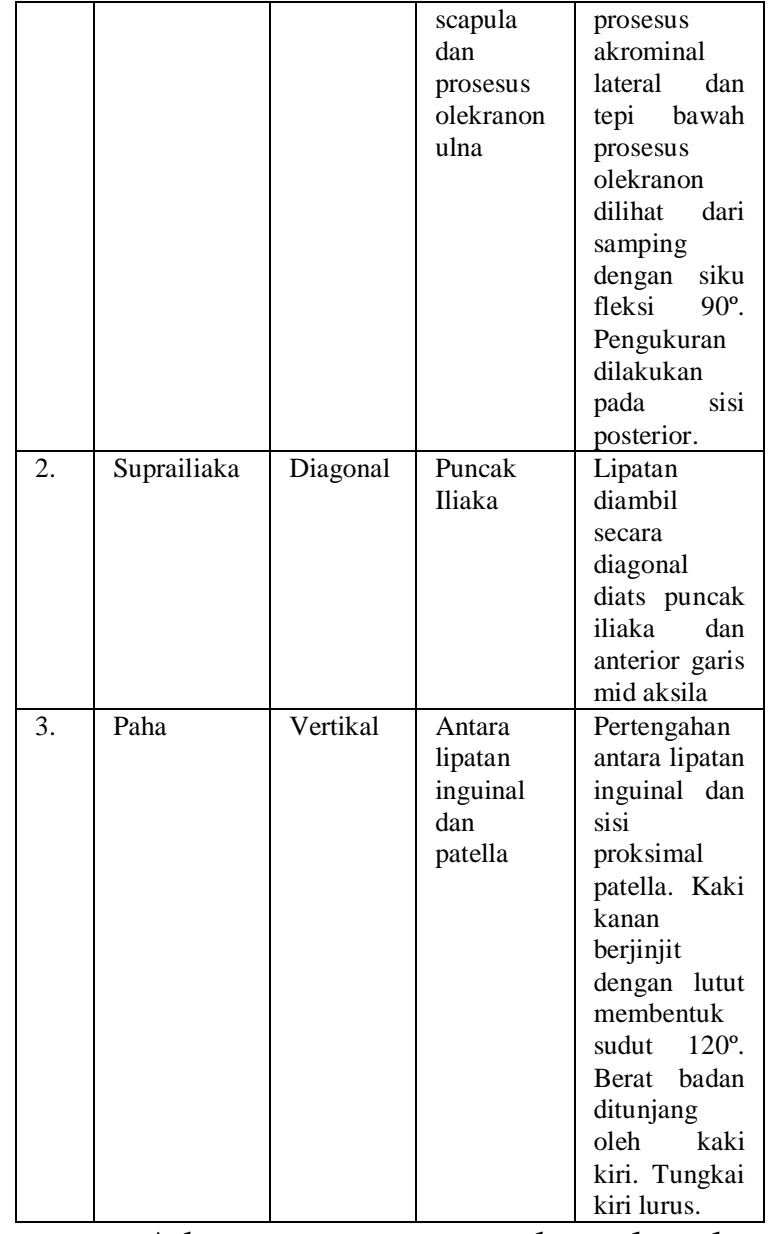

Adapun cara mengukur lemak adalah sebagai berikut :

1. Peserta tes berdiri dengan posisi kedua lengan menggantung disamping tubuh.

2. Bagian yang diukur adalah sisi kanan atau kiri tubuh. Untuk laki-laki pada daerah dada, perut dan paha. Sedangkan untuk perempuan pada daerah triceps, suprailiaka dan paha.

3. Kulit yang diukur dicubit dengan ibu jari dan telunjuk tangan kiri pemeriksa sedemikian rupa sehingga bagian yang dicubit hanya kulit dan lemak saja tanpa mengikutsertakan otot dibawahnya.

4. Kulit yang sudah dijepit kemudian diangkat untuk diukur dengan calliper.

5. Tangan kanan pemeriksa memegang calliperdengan posisi vertikal untuk menjepit lapisan kulit yang telah dicubit dengan tangan kiri.
6. Calliper dijepit $11 \mathrm{~cm}$ dibawah jari yang menjepit dan ditahan selama 2-3 detik.

7. Setiap pemeriksaan dilakukan sebanyak 3 kali dengan perbedaan + atau-1 mm antar setiap pengukuran.

8. Hasilnya adalah rata-rata 3 kali pemeriksaan tersebut.

Kerangka Berpikir. Dari beberapa teori yang telah dikemukakan diatas, dapat disimpulkan bahwa latihan senam aerobik mix impact sangatlah penting karena merupakan salah satu aspek kesegaran jasmani. Senam aerobik tentu saja merupakan kegiatan yang memerlukan banyak oksigen dalam waktu yang lama. Selain untuk kesehatan jantung serta pernafasan, senam aerobik juga berpengaruh terhadap pembakaran lemak tubuh, semakin lama kita melakukan senam aerobik maka akan semakin banyak lemak yang terbakar.

Senam aerobik mix impact merupakan cara terbaik untuk menurunkan prosentase lemak tubuh yang berada diatas normal. Senam aerobik mix impact dapat menurunkan prosentase lemak karena latihan tersebut membutuhkan energi dalam waktu yang cukup lama yaitu antara 45-60 menit. Energi dihasilkan dari pembakaran glukosa untuk menghasilkan kalori, akan tetapi jika sudah habis maka akan menggunakan cadangan energi dari lemak yang tersimpan dibawah kulit yaitu sel adiposa sebagai penggantinya. Untuk itu, latihan senam aerobik mix impact ini harus dilakukan secara teratur dan terprogram agar hasilnya lebih maksimal.

Dengan melakukan latihan jasmani melalui senam aerobik mix impact secara teratur, sistematis dan berulang-ulang dengan penambahan beban setiap minggunya maka lemak yang tadinya menumpuk di bawah kulit dapat terbakar 
dan digunakan sebagai energi pengganti. Dengan demikian lemak tubuh akan berkurang dengan sendirinya. Tubuh akan terlihat lebih ideal dan kesegaran jasmani pun bisa meningkat.

\section{METODE}

Penelitian ini bertujuan untuk mengetahui Pengaruh latihan senam aerobik mix impact terhadap penurunan prosentase lemak tubuh pada wanita penghuni PantiSosial Karya WanitaMulya Jaya Pasar Rebo Jakarta Timur.

Metode penelitian yang akan digunakan adalah metode eksperimen dengan desain penelitian menggunakan One-Groups "Pre-test dan Post-test Design (Pretest - Postest Design)" yaitu untuk mengetahui pengaruh variabel bebas terhadap variabel terikat.

Instrumen Penelitian. Instrumen yang digunakan untuk mengumpulkan data dalam penelitian ini adalah dengan melakukan pengukuran terhadap variabel-variabel yang terdapat dalam penelitian ini, yaitu mengukur prosentase lemak tubuh pada wanita usia 20-29 tahun sebelum dan sesudah melakukan senam aerobik mix impact dengan Fat Calliper.

Teknik Pengumpulan Data. Adapun teknik-teknik pengumpulan data dilakukan sebagai berikut :

1. Alat yang digunakan
a. Fat Calliper
b. Bolpoin dan kertas
c. Stopwatch
d. Kaset senam aerobik
e. Tape / mini kompo
f. Lapangan

2. Pelaksanaan

a. Tes awal (mengukur prosentase lemak dengan menggunakan fat calliper pada bagian tubuh yaitu : triceps, subskapula dan tighsebelum melakukan senam aerobik mix impact).

b. Setelah data didapat maka dihitung dan dimasukkan dalam tabel

c. Melakukan senam aerobik mix impact selama 40-60 menit.

d. Latihan diakhiri dengan pendinginan selama 3-5 menit.

Tes akhir (mengukur prosentase lemak dengan menggunakan fat calliper pada bagian tubuh yaitu: triceps, suprailiaka dan tigh setelah melakukan senam aerobik mix impact.

\section{HASIL DAN PEMBAHASAN}

Deskripsi data pada penelitian ini meliputi nilai tertinggi, nilai rata-rata, standar deviasi, standar error, distribusi frekuensi, serta histogram dari masingmasing variabel, berikut data lengkapnya:

\section{Tabel 1. Deskripsi Data Pengukuran Prosentase lemak Tubuh}

\begin{tabular}{c|c|c} 
Variabel & $\begin{array}{c}\text { Prosentase Lemak } \\
\text { Tubuh } \\
\text { Awal }(\%)\end{array}$ & $\begin{array}{c}\text { Prosentase Lemak } \\
\text { Tubuh } \\
\text { Akhir }(\%)\end{array}$ \\
\hline Nilai tertinggi & 32,0 & 28,7 \\
\hline Nilai terendah & 24,0 & 21,9 \\
\hline Rata-rata & 27,42 & 24,55 \\
\hline $\begin{array}{c}\text { Standar } \\
\text { deviasi }\end{array}$ & 2,06 & 1,62 \\
\hline $\begin{array}{c}\text { Standar } \text { error } \\
\text { Sumber: Hasil Pengolahan Data }\end{array}$ & \begin{tabular}{c}
0,47 \\
\multicolumn{2}{r}{ Sum }
\end{tabular}
\end{tabular}

\section{Data Hasil Pengukuran Prosentase Lemak Tubuh Awal}

Data yang terkumpul mengenai prosentase lemak tubuh pada pengukuran awal menunjukkan rentangan nilai tertinggi $32,0 \%$ dan nilai terendah $25,0 \%$ dengan rata-rata prosentase lemak tubuh awal 27,51\%, standar deviasi (SD) sebesar 1,99standar errormean $\left(\mathrm{SE}_{\mathrm{Mx}}\right)$ sebesar 0,46 (lihat lampiran). Hal tersebut dapat terlihat pada distribusi frekuensi dan histogram berikut: 
Tabel 2. Distribusi Frekuensi Pengukuran Prosentase Lemak Tubuh Awal

\begin{tabular}{c|c|c|c|c} 
No & $\begin{array}{c}\text { Kelas } \\
\text { Interval }\end{array}$ & $\begin{array}{c}\text { Nilai } \\
\text { Tengah }\end{array}$ & $\begin{array}{c}\text { Frekuensi } \\
\text { Absolut }\end{array}$ & $\begin{array}{c}\text { Frekuensi } \\
\text { Relatif }\end{array}$ \\
\hline 1 & $30,5-32,0$ & 31,25 & 4 & $20 \%$ \\
\hline 2 & $28,5-30,0$ & 29,25 & 1 & $5 \%$ \\
\hline 3 & $26,5-28,0$ & 27,25 & 8 & $40 \%$ \\
\hline 4 & $24,5-26,0$ & 25,25 & 6 & $30 \%$ \\
\hline 5 & $22,5-24,0$ & 23,25 & 1 & $5 \%$ \\
\hline \multicolumn{5}{c|}{ Jumlah } \\
Sumber: Hasil Pengolahan Data
\end{tabular}

Dimana nilai prosentase lemak tubuh yang sering muncul adalah rentang kelas interval 26,5-28,0 dengan frekuensi absolut 8 dan frekuensi relatif $40 \%$ dengan nilai tengah kelas tersebut 27,25 .

\section{Data Hasil PengukuranProsentase Lemak Tubuh Akhir}

Data yang terkumpul mengenai prosentase lemak tubuh pada pengukuran akhir menunjukkan rentangan nilai tertinggi $28,7 \%$ dan nilai terendah $21,9 \%$ dengan rata-rata prosentase lemak tubuh $24,55 \%$, standar deviasi (SD) sebesar 1,62 standar error mean $\left(\mathrm{SE}_{\mathrm{Mx}}\right)$ sebesar 0,37. Hal tersebut dapat terlihat pada distribusi frekuensi dan histogram berikut:

\begin{tabular}{|c|c|c|c|c|}
\hline \multicolumn{5}{|c|}{$\begin{array}{c}\text { Tabel 3. Distribusi Frekuensi } \\
\text { Pengukuran Prosentase Lemak Tubuh } \\
\text { Akhir }\end{array}$} \\
\hline No & $\begin{array}{c}\text { Kelas } \\
\text { Interval }\end{array}$ & $\begin{array}{l}\text { Nilai } \\
\text { Tengah }\end{array}$ & $\begin{array}{c}\text { Frekuensi } \\
\text { Absolut }\end{array}$ & $\begin{array}{c}\text { Frekuensi } \\
\text { Relatif }\end{array}$ \\
\hline 1 & $27,4-28,7$ & 28,5 & 1 & $5 \%$ \\
\hline 2 & $25,8-27,1$ & 26,45 & 6 & $30 \%$ \\
\hline 3 & $24,2-25,5$ & 25,65 & 4 & $20 \%$ \\
\hline 4 & $22,6-23,9$ & 23,25 & 8 & $40 \%$ \\
\hline 5 & $21,0-23,3$ & 21,65 & 1 & $5 \%$ \\
\hline \multicolumn{3}{|c|}{ Jumlah } & 20 & $100 \%$ \\
\hline
\end{tabular}

Dimana nilai prosentase lemak tubuh yang sering muncul adalah rentang kelas interval 22,6-23,9 dengan frekuensi absolut 8 dan frekuensi relatif
$40 \%$ dengan nilai tengah kelas tersebut 23,25 .

Pengujian Hipotesis. Disampaikan tentang nilai rata-rata $(\bar{X})$ dari hasil yang didapatkan pada tes awal 27,51\% dan pada tes akhir $24,55 \%$ dari data ratarata mengenai tes awal dan tes akhir pada prosentase lemak tubuh menunjukkan adanya penurunan hasil yang didapat. Dari hasil analisis data diperoleh selisih rata-rata $\left(M_{D}\right) \quad 2,96$ dengan standar deviasi perbedaan $\left(S D_{D}\right)$ 0,94 standar error perbedaan rata-rata $\left(S E_{M D}\right) \quad 0,22$ dalam perhitungan selanjutnya diperoleh nilai t-hitung sebesar 13,45 dan nilai t-tabel dengan derajat kebebasan (n-1) dan taraf signifikan $\alpha=0,05$ didapat sebesar 2,09 yang berarti t-hitung $=13,45$ lebih besar dari t-tabel $=2,09$. Hal ini menunjukan bahwa hipotesa nihil $\left(\mathrm{H}_{\mathrm{o}}\right)$ ditolak dan hipotesa alternatif $\left(\mathrm{H}_{1}\right)$ diterima.

Dari hasil perhitungan tersebut dinyatakan bahwa latihan senam aerobic mix impact berpengaruh terhadap penurunan prosentase lemak tubuh pada wanita penghuni panti social karya wanita Mulya Jaya Pasar Rebo Jakarta Timur.

\section{PENUTUP}

Kesimpulan. Berdasarkan hasil pengukuran dan analisa yang dilaksanakan dalam penelitian ini maka dapat disimpulkan bahwa latihan senam aerobik mix impact berpengaruh signifikan terhadap penurunan prosentase lemak tubuh. Dengan kata lain, terjadi penurunan prosentase lemak tubuh setelah mengikuti latihan senam aerobik mix impact pada wanita penghuni panti sosial karya wanita Mulya Jaya Pasar Rebo Jakarta Timur.

Saran. Dari hasil penelitian ini, peneliti ingin menyampaikan saran-saran sebagai berikut: 
1. Melakukan penelitian lebih lama untuk efektifitas latihan.

2. Untuk yang ingin melakukan penelitian yang serupa agar memperhatikan faktor-faktor yang dapat mempengaruhi hasil penelitian, seperti tidak melakukan olahraga lain selain senam serobik mix impact.

3. Mensosialisasikan kepada seluruh mahasiswa fakultas olahraga khususnya dan masyarakat pada umumnya bahwa dalam melakukan olahraga sebaiknya yang bersifat aerobik seperti senam aerobik mix impact sebagai salah satu upaya untuk mengontrol prosentase lemak tubuh.

4. Perlunya pengaturan kalori yang masuk dan keluar secara berkesinambungan supaya lemak ada dalam tubuh keadaan yang seimbang.

\section{DAFTAR RUJUKAN}

Achmad D. Sediaoetama, Ilmu Gizi. Jakarta: Dian Rakyat, 2004.

Asdep Kementrian Pemuda dan Olahraga. Menjadi Pelatih Mental Bagi Olahragawan, Jakarta, 2010.

Dede Kusmana, Olahraga Bagi Kesehatan Jantung, Jakarta: Fakultas Kedokteran Universitas Indonesia, 2001.Tudor, O Bompa, Theory and Methodology of Training. Jakarta: Terjemahan.

Depkes RI Dirjen Binkesmas Direktorat Kesehatan Komunitas, Petunjuk Teknis Pengukuran Kebugaran Jasmani, 2005.

Harsono, Coaching dan Aspek-Aspek Psikologi dalam Coaching. Jakarta: Depdikbud, Ditjend Dikti, PPLPTK, 1988.

Hertog Nursanyoto, dkk. Ilmu Gizi, Jakarta: PT. Golden Terayon Press, 1992.

Lynne Brick, Bugar dengan Senam Aerobik, Terjemahan Anna Agustina, Jakarta: PT. Rajagrafindo Persada, 1986.
Sadoso Sumosardjono, Olahraga dan

Kesehatan, Jakarta: Pustaka Kartini, 1989.

Sadoso Sumosardjono, Olahraga dan Kesehatan, Jakarta : PT Gramedia, 1986.

Sunita Almatsier, Prinsip Dasar Ilmu Gizi, Jakarta: PT. Gramedia Pustaka Utama, 2002.

S. Nasution, Metode Research, Jakarta: Bumi Aksara, 2007. 